\title{
THE EFFECT OF EXECUTIVE COMPENSATION, REPRESENTATION OF CHIEF FINANCIAL OFFICER'S WOMEN, EXECUTIVE CHARACTERISTIC ON TAX AGGRESSIVENESS
}

\author{
Listya Sugiyarti \\ Program Studi Akuntansi Fakultas Ekonomi Universitas Pemulang \\ listya.sugiarti@unpam.ac.id
}

\begin{abstract}
The Effect of Executive Compensation, Representation of Chief Financial Officer's Women, Executive Characteristic on Tax Aggressiveness. The purpose of this study was to determine the effect of executive compensation, female CFO representation, executive characteristics on tax aggressiveness in companies listed on the Indonesia Stock Exchange for the period 2013-2017. The population in this study were manufacturing companies on the Indonesia Stock Exchange for the period 2013-2017. The number of manufacturing companies sampled in this study were 12 companies with 5 years of observation. Based on the purposive sampling method, the total sample is 60 financial report data. This study uses multiple linear regression analysis techniques, $t$ test with the application of the SPSS 24 program. The results of this research showed that the variables of executive compensation have a positive and significant impact on aggressiveness tax, Representation of Chief Financial Officer (CFO) Women has no significant on aggressiveness tax, and the variable executive characteristic has a negative and significant impact on aggressiveness tax. Simultaneously, executive compensation, Representation of Chief Financial Officer (CFO) Women and executive characteristics have an impact on tax aggressiveness.
\end{abstract}

Keywords: Executive Compensation, Representation of Chief Financial Officer (CFO) Women, Executive Characteristics, Tax Aggressiveness

\begin{abstract}
Abstrak: Pengaruh Kompensasi Eksekutif, Keterwakilan CFO Wanita, Karakteristik Eksekutif terhadap Agresivitas Pajak. Tujuan dari penelitian ini adalah untuk mengetahui pengaruh kompensasi eksekutif, keterwakilan CFO wanita, karakteristik eksekutif terhadap agresivitas pajak pada perusahaan yang terdaftar di Bursa Efek Indonesia periode 2013-2017. Populasi dalam penelitian ini adalah perusahaan manufaktur di Bursa Efek Indonesia periode 2013-2017. Jumlah perusahaan manufaktur yang dijadikan sampel dalam penelitian ini adalah 12 perusahaan dengan pengamatan selama 5 tahun. Berdasarkan metode purposive sampling, total sampel adalah 60 data laporan keuangan. Penelitian ini menggunakan tehnik analisis regresi linier berganda, uji t dengan aplikasi program SPSS 24. Hasil penelitian ini menunjukkan bahwa secara parsial variabel kompensasi eksekutif berpengaruh positif dan signifikan terhadap agresivitas pajak, keterwakilan CFO wanita tidak berpengaruh signifikan terhadap agresivitas pajak, dan karakteristik eksekutifmemiliki pengaruh negatif dan signifikan terhadap pajak agresivitas.
\end{abstract}

Kata kunci: Kompensasi Eksekutif, Keterwakilan CFO Wanita, Karakteristik Eksekutif, Agresivitas Pajak

\section{INTRODUCTION}

Tax is one of the main sources of income for a country in the framework of financing government administration for the provision of public goods and services and development. In the explanation of the law on general provisions and procedures for taxation (UU KUP), it has been stated that tax is one of the means and rights of each taxpayer to participate in the administration of the state and development. But for business people and investors, fixed taxes are 


\section{Nominal: Barometer Riset Akuntansi dan Manajemen}

P-ISSN: 2303-2065 E-ISSN: 2502-5430

Volume 10 No 2 (2021)

considered as an investment expense. Therefore, it is natural that employers try to avoid the tax burden by making effective tax planning. Tax avoidance can occur in the sound of provisions or is written in the law. This is done so that the company recognizes high debt interest. Based on Law No.36 of 2008 concerning Income Tax, interest on the debt is allowed to be a deduction from taxable income. Therefore, taxpayers use this method to minimize tax due but do not violate existing tax regulations. Tax avoidance must be distinguished from tax evasion which generally has an illegal nature and includes actions who intentionally do not report completely and correctly the object of tax or fraud. Although legally distinguishable, economically both tax planning through tax avoidance and tax evasion are both resulting in reduced tax revenues. Engineering (arrangements) for transactions that have the potential to minimize the tax burden to obtain tax savings are tax planning.

Meanwhile, smuggling or tax evasion and the like mainly occur with the disappearance or lack of reporting of tax objects that are sometimes supported by legal, accounting and another administrative engineering. While aggressive tax is a tax plan that is between tax avoidance and tax evasion, it is in the grey area.
Tax planning is one of the company's planning activities related to business activities carried out by employers to be able to perform obligations and obtain rights related to taxation, which will hurt the company or businessman.

Tax avoidance cases show that most of these actions are motivated by the company's efforts to avoid taxation and tax savings, to reduce the cost of tax payments to be smaller. This is supported by the principle of the company that is trying to generate maximum profit by reducing company costs including reducing the cost of paying taxes.

Aggressive tax actions can provide marginal benefits and marginal costs. Marginal benefits that may be obtained are the existence of significant tax savings for the company, while the marginal cost that may arise is the emergence of fees for the possibility of tax penalties or fines being imposed if audited, the company's stock price decreases. This aggressive tax action is measured using an effective tax rate (ETR). ETR is used because it is considered to be able to reflect the fixed difference between book profit calculation and fiscal profit (Frank et al., 2009: 471).

Compensation is an important component in creating effective and conducive management. Compensation is part of management. A good compensation system can provide a significant contribution 


\section{Nominal: Barometer Riset Akuntansi dan Manajemen}

P-ISSN: 2303-2065 E-ISSN: 2502-5430

Volume 10 No 2 (2021)

to business success. A good compensation system can make a significant contribution to business success. The compensation system helps in strengthening the organization's key values and facilitates the achievement of organizational goals (Sutrisno, 2011: 181). Compensation is also a driving force for someone at work because it affects morale and labor discipline. Compensation is an important factor in influencing how and why people work in an organization and not in other organizations.

The policy of determining executive compensation is one way that can be done to support improvements in performance. The executive is responsible for optimizing the profits of the owners or shareholders, and in return, the executive will receive compensation following the contract. The company owner expects the executive to improve performance with the right compensation policy (Santi and Puji, 2014 in Khasanah, 2015: 5).

Previously there was Armstrong et al. (2012) conducted a study on the relationship of compensation received by company executives, especially for compensation received by the tax director, against the company's tax planning. In the study, it proved a significant relationship between the compensation received by the tax director and tax planning through Generally Accepted
Accounting Principles (GAAP) effective tax rates.

Aggressive tax actions can arise from various factors, one of which is compensation. This is done by improving the company's performance to be better and more efficient. One of the strategies carried out by management is the efficiency of tax payments (Putri, 2016:2). Besides compensation for aggressive tax actions, it can also arise from other factors, regarding women's representation as Chief Financial Officer (CFO). However, in the financial statements of the Chief Financial Officer (CFO) and the Chief Executive Officer (CEO) are the main parties that have direct influence, both of them are parties who enter into financial statements and are responsible for the information presented. In other studies shows that female CFOs have a significant effect on earnings management levels. Therefore, this study wants to examine how the influence of the Representation of Chief Financial Officer (CFO) Women on aggressive tax actions on companies in Indonesia, especially the manufacturing industry.

In addition to wanting to examine the effect of executive compensation and the Representation of Chief Financial Officer (CFO) Women on aggressive tax actions, this study also wants to examine how the influence of executive characteristics on 


\section{Nominal: Barometer Riset Akuntansi dan Manajemen}

P-ISSN: 2303-2065 E-ISSN: 2502-5430

Volume 10 No 2 (2021)

companies against aggressive tax actions. A company leader can have the character of a risk-taker or risk-averse which is reflected in the size of the company risk (Budiman and Setiyono, 2012). Corporate leaders who are risk-takers will tend to be more courageous in making decisions even though the emissary is at high risk. Conversely, executives who have risk-averse character will tend to be more careful, because even if they do not violate the Law, imposing unnatural costs can create opportunities for tax audits.

The provision of a compensation package can be used to solve the problem of moral hazard management, as well as to find a positive relationship between the level of compensation and corporate tax aggressive behavior associated with company performance. Minnick and Noga, (2010) found a negative relationship between increased compensation and corporate tax payments. Providing a high level of compensation will encourage a decrease in the company's effective tax rates, which is one way to measure the value of tax aggressiveness.

Several researchers have conducted research by linking the company's financial condition to tax aggressiveness. Research conducted by Siahaan and Mustikasari in Sari (2016: 6) with high profitability tends to report taxes honestly than companies that have low profitability. Low profitability may reflect that the company is having difficulty meeting short-term obligations. Return on Assets (ROA) is an indicator that reflects the company's financial performance, the higher the ROA value, the better the company's performance. ROA relates to the company's net income and the imposition of income taxes for corporate taxpayers. The higher the value of the ROA, the higher the value of the company's net income and the higher its profitability.

Sari and Martani, (2010) turns out that the level of tax aggressiveness of family companies is smaller than non-family companies. This occurs because it is suspected that family owners are more willing to pay higher taxes than have to pay tax penalties and face the possibility of damaging the company's reputation due to audits from the tax authorities, which indicates that non-family companies have a higher level of tax aggressiveness than family companies. occurs because agency problems are larger in non-family firms. Family companies are more willing to pay taxes than to pay tax penalties and possibly tarnish the reputation of the company.

Based on the description above, This purpose of this research is to determine the effect of executive compensation, Representation of Chief Financial Officer 
(CFO) Women, executive characteristic on tax aggressiveness.

\section{LITERATURE REVIEW}

\section{Agency Theory}

Agency relations occur when one party (principal) hires another party (agent) to carry out a service and delegate authority to decide to the agent. Within the company, the CEO and CFO are agents and shareholders are principals. One element of agency theory is that principals and agents have different preferences or goals. According to Brigham and Houston, (2001), that managers are given power by the owner of the company (shareholders), to make decisions, which creates a potential conflict of interest known as the agency theory.

This agency theory arises when there is an employment relationship agreement which principally has authority with the agent or the party given the authority to run the company. In this case, the agency relationship manager occurs when one party (principal) hires another party (agent) must provide information to the owner of the company regarding the condition of his company. But sometimes the manager does not fully report the state of the company following the reality and this is what the manager can do to benefit the manager or performance from a manager. This kind of action is usually done because of various agency problems such as excessive spending.

Differences in interests between the owner of the company and the agent can affect various matters relating to the performance of the company, one of which is about corporate tax policy. In Indonesia, the system adopted is a self-assessment system that gives companies the authority to calculate and report their taxes.

The use of this system can certainly provide an opportunity for agents to manipulate data regarding taxable income to be lower so that the tax burden borne by the company becomes smaller.

Various ways are used to control the agent's actions related to the tax management activities carried out, namely by evaluating the results of the company's financial statements using financial ratios compared to aggressive tax actions that may be carried out by the agent. The ratio that can be used is the size of the company, profitability, leverage, and capital intensity which is compared to the effective tax rate (ETR) of the company derived from the tax expense compared to the profit before tax. The company can be classified as a large company when the company has a high total asset because if the total assets increase or increase then the number of the company's profits is large. The greater the profit of the company means that the amount of tax that must be paid is also 


\section{Nominal: Barometer Riset Akuntansi dan Manajemen}

P-ISSN: 2303-2065 E-ISSN: 2502-5430

Volume 10 No 2 (2021)

large, but it could be that the agent does data manipulation so that it must be compared with the size of the company's ETR.

\section{Executive Compensation}

Compensation is an important function in management because compensation is the most sensitive aspect of the working relationship. Executive compensation is an important component in creating effective and conducive management. A good compensation system can make a significant contribution to business success. Compensation is all income in the form of money, goods directly or indirectly received by employees as compensation or services provided to the company (Hasibuan, 2011: 118). The compensation system helps in strengthening the key values of the organization and facilitates the achievement of organizational goals (Sutrisno, 2011: 181).

The compensation problem is sensitive, it is also a driver for someone to work because it affects the morale and discipline of the workforce. A good compensation system can make a significant contribution to business success (Khasanah, 2015: 4). Compensation is an important factor that influences how and why people work in an organization and not in other organizations (Kadarisman, 2012: 26). Compensation is a counter-achievement against the use of labor or services provided by labor. Compensation becomes a kind of package offered by the organization to workers in return for the use of their workforce (Wibowo, 2013: 348).

Based on the above understanding, it can be concluded that compensation is a form of appreciation given to workers whose numbers depend on the results achieved both financially and non-financially. This is intended to encourage the workforce to work harder and better so that achievement can be increased which ultimately can be achieved. Fen, S., and Riswandari, E. (2019) states that the executive is a person who occupies a certain leadership position in an organization and has the right and authority to move others called "subordinates" and the subordinates who bear the responsibility of carrying out various operational activities in achieving the objectives of the top-level managers of an organization that have a large influence on the company, such as the president director, vice president, director, executive manager, including the president commissioner and commissioner.

The policy of determining executive compensation is one of the ways that can be done to encourage performance improvements. The executive is responsible for optimizing the profits of the owners or shareholders, and in return, the executive will receive compensation following the contract. The company owner expects the executive to improve performance with the right policy of 
compensation (Santi and Puji, 2014 in Khasanah, 2015: 5).

Representation of Chief Financial Officer (CFO) Women

CFO (Chief Financial Officer) is a position in a company that has the first responsibility for managing the company's financial risk. This official is also responsible for financial planning and financial recording and reporting for higher management. In some sectors, the CFO is also responsible for data analysis. In the CEO and CFO, companies are parties directly involved, namely both parties who sign the financial statements and are responsible for the information presented.

Men and women have differences that can be viewed from two kinds of concepts, namely the biological concept that emphasizes gender and non-biological concepts which are better known as the concept of gender. There are two theories to see the existence of psychological differences, those are tears Nature and the Nurture theory (Partini, 2013 and Rahayu, 2016). Followers of Nature theory assume that the psychological differences between men and women are caused by biological factors. Whereas followers of the Nurture theory assume that differences are created through the learning process of the environment.
Role theory pays attention to differences between genders which are expressed through differences in expectations, attitudes, behavior that have patterned, and possibly psychological characteristics. Men are considered to have higher intellectuality and emotions, and want meaningful work with greater expectations than women (Partini, 2013; Rahayu, 2016).

The female director has a different work experience compared to male directors. Female directors have a better understanding of the company's market segment than men and this can develop quality in the company's decision-making process. Peni and Vähämaa (2010) and Gonçalves, Gaio, and Santos, T. (2019) states that the existence of one of the $\mathrm{CEO}$ and CFO wan I ta women will reduce the level of earnings management. Meanwhile, Francis et al., (2014: 27) states that women's CFOs influence aggressive tax actions. In other words, the Representation of Chief Financial Officer (CFO) Women has a significant effect on aggressive tax actions.

\section{Executive Characteristics}

Executives who have the character of risk-takers are executives who are more courageous in taking business decisions and usually have a stronger urge to have higher income, position, welfare, and authority (MacCrimon and Wehrung, 1990: 423). Executives who have the character of risk- 
takers do not hesitate to finance debt (Lawellen, 2003).

Executives who have character riskaverse executives who tend to dislike risk, so less bold in making decisions. The riskaverse executive if he gets a chance then he will choose a lower risk. Usually, risk-averse executives have an older age, have held positions for a long time, and have a dependency on the company (Maccrimon and Wehrung, 1990).

According to Budiman and Setiyono (2012: 4), the risk is related to the return obtained by the company, that the risk is a deviation or deviation from the outcome received with the expected indicates the greater the risk that exists. Rahayu (2016) defines the risk of the company (corporate risk) is volatility corporate earnings, which can be measured by the standard deviation formula. Therefore, the corporate risk is a deviation or standard deviation from earnings, whether the deviation is less than planned (downside risk) or perhaps more than planned (potential upside). The greater the deviation of the company's earnings indicates the greater the risk of the existing company, the high and low risk of the company indicates whether the executive character includes risk-taker or risk-averse.

\section{Aggressive Taxes}

Aggressive tax acts as a management action that aims to reduce taxable income through tax planning either using a method that is classified as tax evasion or not. Tax evasion is an effort made by a taxpayer to reduce the tax burden and obtain tax savings by conducting tax planning which is generally illegal and includes intentionally not reporting completely and correctly the tax object or other violations of fraud. While tax avoidance deals with setting up an event in such a way as to minimize or eliminate the tax burden by paying attention to whether or not there are tax consequences. Therefore, tax avoidance does not constitute a violation of tax legislation or is not considered ethically wrong in the framework of the taxpayer's business to reduce, avoid, minimize or alleviate the tax burden in ways made possible by law (Ernest R. Mortenson in Mochammad Zain, AK). Aggressive tax action is the main objective of tax planning activities to avoid paying taxes or making a low tax burden paid significantly. And it can be concluded that aggressive tax action is carried out as the last attempt of the spectrum of a series of tax planning behaviors to reduce the tax burden and tax savings which can later produce aggressive tax reporting.

In doing aggressive tax measures, there are advantages and disadvantages. Chen et al. (2010: 8) mention 3 advantages of aggressive tax actions, namely:

1. The benefits in the form of tax savings paid by the company to Neagra, 
so that the cash portion for shareholders becomes greater.

2. Compensation for managers from shareholders for aggressive tax actions by the manager.

3. The opportunity for managers to conduct rent extraction, that is, the actions of managers who do not maximize the interests of the owner. This can be in the form of aggressive financial statements, taking company resources or assets for personal gain, or conducting transactions with parties that have a special relationship. While 3 losses from aggressive tax actions, namely:

1) There is a possibility that the company is subject to penalties from taxation agencies due to the discovery of frauds that may occur during the audit process.

2) The damage to the company's reputation due to audits by taxation agencies.

3) The decline in the company's stock price due to the assumption of the shareholders that aggressive tax actions carried out by managers is an act of rent extraction that can harm shareholders.

Aggressive tax actions can be measured in various ways. Aggressive tax action has five measurement components, namely effective tax rate (ETR), cash effective tax rate
(CETR), book-tax difference of ManzonPlesko (BTD_MP), book-tax difference Design-Dharmapala (BTD_DD) and tax planning (TAXPLAN) (Sari and Martani, 2010: 10).

ETR is used because it is considered to reflect the fixed difference between book profit calculation and fiscal profit. While CETR is used because it is expected to identify the aggressiveness of corporate tax planning, book-tax difference can arise because of tax planning and tax planning (TAXPLAN) is used because it can describe the level of tax subsidies used.

It can be concluded that aggressive tax actions are carried out as the most recent effort of the spectrum of a series of tax planning behaviors to reduce the tax burden and tax savings that the partners can produce aggressive tax reporting.

\section{Hypothesis Development}

\section{Executive Compensation Influence on}

\section{Aggressive Tax Measures}

Compensation is an important component in creating effective and conducive management. A good compensation system can make a significant contribution to business success. The compensation system helps in strengthening the key values of the organization and facilitates the achievement of organizational goals (Sutrisno, 2011: 181). The results of 
previous research by Rahayu (2016), who researched the Effect of Executive Compensation, Representation of Chief Financial Officer (CFO) Women and Executive Characteristics on Aggressive Tax Measures, the results of this study indicate that Executive Compensation influences aggressive tax actions. Based on the description above, the first hypothesis is :

H1: Executive compensation affects aggressive tax actions.

\section{Representation of Chief Financial Officer} (CFO) Women Influence Aggressive Tax Actions.

Based on research conducted Rahayu (2016) who researched the Effect of Executive Compensation, Representation of Chief Financial Officer (CFO) Women and Executive Characteristics on Aggressive Tax Actions. The results of this study indicate that the relationship of female $\mathrm{CFO}$ affects aggressive tax action. Based on the description above, the second hypothesis is:

H2: Representation of Chief Financial Officer (CFO) Women burden affects aggressive tax actions.

\section{The Characteristics of Executives}

\section{Influence Aggressive Tax Actions}

Based on research conducted by Dewi and Jati (2014) who researched the influence of executive characteristics, company characteristics, and good corporate governance dimensions on tax avoidance, the results of this study indicate that the Executive Characteristics affect aggressive tax actions. Based on the description above, the third hypothesis is:

H3: The characteristics of the executive affect aggressive tax actions.

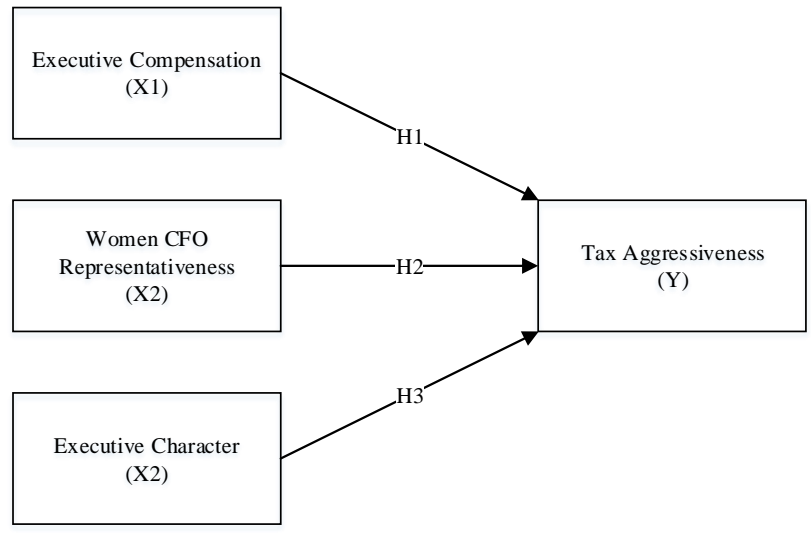

Figure 1. Research Design

\section{RESEARCH METHOD}

To determine the number of samples needed, the method of determining the sample is a non-probability sampling method, namely the sampling method used does not provide an opportunity or opportunity for each element or member of the population to be selected as a sample or sampling method that is determined by the researcher or in consideration expert. In this study, researchers used secondary data obtained from consumer goods sub-sector manufacturing companies listed on the Indonesia Stock Exchange during the period 2013-2017 which can be accessed through the www.idx.co.id site. To determine the sample, the researcher used a purposive 
sampling method from a population of 37 companies and with the predetermined criteria by the authors 12 companies met the criteria. the number of companies that can be sampled during the study period from 20132017 is as much as 60 observation data and all required data complete.

\section{RESULT AND DISCUSSION}

\section{Result}

\section{Descriptive Statistics}

The results of the descriptive (see table 1) statistics of the Executive Compensation variable with the number $\mathrm{N}$ as many as 60 shows the minimum value of 19.00 . Furthermore, Executive Compensation has a maximum value of 27.00, The average Executive Compensation with a total $\mathrm{N}$ of 60 is 23,0000 and companies that are above the average of 4 manufacturing companies in the consumer goods sub-sector, which are above the average, indicate that the consumer goods company can get high profits.

Descriptive statistics of female $\mathrm{CFO}$ Representative variables with a total $\mathrm{N}$ of 60 indicates a minimum value of 0.00 , a maximum value of 1.00. Average Representation of Chief Financial Officer (CFO) Women with a total $\mathrm{N}$ of 60 is equal to 0.1000 , which is above this average indicating that the company has a Representation of Chief Financial Officer (CFO) Women in its company.
The results of descriptive statistics of Executive Characteristic variables with the number of $\mathrm{N}$ as many as 60 shows a minimum value of 0.04 , Furthermore, the Executive Characteristics has a maximum value of 0.48 , The average Executive Characteristics with a total $\mathrm{N}$ of 60 is 0.1677 , which is above the average indicating that the consumer goods company has high executive characteristics.

Table 1. Table of Descriptive Statistic by Variable Data

\begin{tabular}{ccccc}
\hline Var. & N & Min & Max & Mean \\
\hline $\begin{array}{c}\text { Executive } \\
\text { Compensation }\end{array}$ & & 19.00 & 27.00 & 23.00 \\
$\quad$ (X1) & 60 & & & \\
$\begin{array}{c}\text { Representation } \\
\text { of Chief } \\
\text { Financial }\end{array}$ & & 0.00 & 1.00 & 0.10 \\
$\begin{array}{c}\text { Officer (CFO) } \\
\text { Women (X2) } \\
\text { Executive }\end{array}$ & 60 & & & \\
$\begin{array}{c}\text { Characteristics } \\
(X 3)\end{array}$ & 60 & 0.04 & 0.48 & 0.17 \\
$\begin{array}{c}\text { Aggressive } \\
\text { Tax Actions } \\
\quad(Y)\end{array}$ & 60 & 0.18 & 0.35 & 0.25 \\
$\begin{array}{c}\text { Valid N } \\
\text { (listwise) }\end{array}$ & 60 & & & \\
\hline
\end{tabular}

\section{Hypotheses test}

Based on table 2 , it is known that executive compensation has a significant value of 0.032 , where the value of 0.032 $<0.05$ and $t$ count $>\mathrm{t}$ table is $2.199>2.003$. so it can be concluded that there is a significant influence between executive compensation on aggressive tax actions so that in this research $\mathrm{H} 1$ is accepted. Based on the above table it is known that the Representation of Chief Financial Officer 
(CFO) Women has a significant value of 0.554 , where the value is $0.554>0.05$ and $t$ count $<\mathrm{t}$ table is $-0.595<2.003$. so it can be concluded that there is no significant effect between Representation of Chief Financial Officer (CFO) Women on aggressive tax actions so that in this study $\mathrm{H} 2$ is rejected. Based on the table above, it is known that executive characteristics have a significant value of 0.039 , where $0.039<0.00$ and $t$ count $<\mathrm{t}$ table, namely $-2.110<2.003$. So it can be concluded that there is a significant influence between executive characteristics on aggressive tax action so that in this study H3 was accepted.

Table 2. Statistical T-Test Results

\begin{tabular}{|c|c|c|c|}
\hline Model & $\begin{array}{c}\text { Unstandardized } \\
\text { Coefficients }\end{array}$ & $\mathbf{T}$ & Sig. \\
\hline (Constant) & 0.175 & 4,147 & 0 \\
\hline Executive & & & \\
\hline $\begin{array}{l}\text { Compensation } \\
\text { (X1) }\end{array}$ & 0.004 & 2,199 & 0.032 \\
\hline $\begin{array}{l}\text { Representation } \\
\text { of Chief }\end{array}$ & & & \\
\hline $\begin{array}{l}\text { Financial } \\
\text { Officer }(C F O) \\
\text { Women }(X 2)\end{array}$ & -7 & -595 & 0.554 \\
\hline $\begin{array}{l}\text { Executive } \\
\text { Characteristics } \\
\text { (X3) }\end{array}$ & -0.082 & $-2,110$ & 0.039 \\
\hline $\begin{array}{l}\text { Aggressive Tax } \\
\text { Actions (Y) }\end{array}$ & & & \\
\hline
\end{tabular}

\section{Discussion}

Executive compensation affects aggressive tax actions

The results of this study indicate that there is a significant effect of executive compensation on aggressive tax actions measured by using a nominal scale of total compensation. Executive compensation has a significant value of 0,032 were $0,032<0.05$ so that in this study H1 is accepted.

\section{Representation of Chief financial Officer (CFO) Women does not affect aggressive} tax actions

The results of this study indicate that there is no significant effect of female $\mathrm{CFO}$ representation on aggressive tax actions measured by using dummy variables. Representation CFOwoman has a significant value of $-0,595$ where $-0.595>0.05$ so that in this study the $\mathrm{H} 2$ was rejected.

The characteristics of the executive affect the aggressive tax action

The results show that there is a significant influence on executive characteristics and aggressive tax actions that are measured using Corporate risk which affects aggressive tax actions. Executive characteristics have a significant value of $0.039<0.005$ so that in this study H3 was accepted.

\section{CONCLUSION}

This study aimed to get empirical evidence of the influence of executive compensation, representation $\mathrm{CFO}$ woman and characteristics of the executives of the tax measures aggressive. From the description and discussion, the conclusions 
can be drawn at the end, including the following:

1. The results show that partially the Executive Compensation variable influences the Aggressive Tax Actions. The results of this study are the same as research conducted by Rahayu (2016) which proves that executive compensation has a significant effect on tax aggressive actions in the coming year, which finds that executive compensation is proxied by the natural logarithm of the total compensation received by the executive for one year. year. This shows that the lower the compensation provided by the company to executives, the higher the probability of tax aggressive action. By providing low compensation to executives, it will motivate executives to reduce corporate taxes.

2. The results showed that partially the female $\quad \mathrm{CFO}$ representation did not affect the aggressive tax action. The results of this study are inconsistent with previous research conducted by Peni and Vähämaa (2010) which proved that female CFO representation has an effect on earnings management. Limited number of samples and years for female CFO representation compared to male CFO representation in consumer goods sub-sector manufacturing companies in
2011-2015 which are thought to be differences in the results of previous studies.

3. The results of the study show that partially the Executive Characteristics variable influences the Aggressive Tax Actions. These results support the research of Budiman and Setiyono (2014), who found that executive characteristics influence tax aggressive action. This means that the higher the corporate risk value, the lower the probability of tax aggressive action. This means that companies that have a high corporate risk value or have executives will tend to present financial reports as is to see how far the company has performed so that the opportunities for tax avoidance are low.

\section{REFERENCE}

Armstrong, C. S., Blouin, J. L., \& Larcker, D. F. (2012). The incentives for tax planning. Journal of accounting and economics, 53(1-2), 391-411.

Barua, A., Davidson, L. F., Rama, D. V., \& Thiruvadi, S. (2010). CFO gender and accruals quality. Accounting Horizons, 24(1), 25-39.

Brigham, E. F., \& Houston, J. F. (2001). Manajemen Keuangan (8th ed.). Jakarta: Erlangga.

Budiman, Judi \& Setyono Miharjo (2012). Pengaruh Karakter Eksekutif terhadap Penghindaran Pajak (Tax Avoidance) (Doctoral dissertation, 
[Yogyakarta]: Universitas Gadjah Mada).

Chen, S., Chen, X., Cheng, Q., \& Shevlin, T. (2010). Are family firms more tax aggressive than non-family firms?. Journal of Financial Economics, 95(1), 41-61.

Dewi, N., \& Jati, I. (2014). Pengaruh Karakter Eksekutif, Karakteristik Perusahaan dan Dimensi Tata Kelola Perusahaan yang Baik pada Tax Avoidaance di Bursa Efek Indonesia. E-Jurnal Akuntansi, 6(2),249-260.

Lewellen, K. \& Demers, E. (2003). The marketing role of IPOs: evidence from internet stocks. Journal of Financial Economics, 68(3), 413437.

Fen, S., \& Riswandari, E. (2019). Effect of Executive Compensation, Representatives of Female CFO, Institutional Ownership and Company Sizes on Tax Agressivity Measures. EAJ (Economics and Accounting Journal), 2(2), 104-123.

Frank, M. M., Lynch, L. J., \& Rego, S. O. (2009). Tax reporting aggressiveness and its relation to aggressive financial reporting. The Accounting Review, 84(2), 467-496.

Francis, B. B., Hasan, I., Wu, Q., \& Yan, M. (2014). Are female CFOs less tax aggressive? Evidence from tax aggressiveness. The Journal of the American Taxation Association, 36(2), 171-202.

Gonçalves, T., Gaio, C., \& Santos, T. (2019). Women on the Board: Do They Manage Earnings? Empirical Evidence from European Listed Firms. Revista Brasileira de Gestão de Negócios, 21(3), 582-597.
Hasibuan, Malayu SP 2017. Management of Human Resources. Earth Literacy. Jakarta.

Kadarisman, M. Compensation Management. 2012. Rajagrafindo. Jakarta

Khasanah, A. N. (2016). Pengaruh intellectual capital dan islamicity performance index terhadap kinerja keuangan perbankan syariah di Indonesia. Nominal, Barometer Riset Akuntansi dan Manajemen, 5(1), 118.

MacCrimmon, K. R., \& Wehrung, D. A. (1990). Characteristics of risk taking executives. Management Science, 36(4), 422-435.

Minnick, K., \& Noga, T. (2010). Do corporate governance characteristics influence tax management? Journal of Corporate Finance, 16(5), 703-718. https://doi.org/10.1016/j.jcorpfin.2010. 08.005

Partini. 2013. Gender Bias in Bureaucracy Edition 2. Tiara Wacana. Yogyakarta.

Peni, E., \& Vähämaa, S. (2010). Female executives and earnings management. Managerial Finance, 36(7), 629-645. https://doi.org/10.1108/0307435101105 0343

Putri, C. L., \& Lautania, M. F. (2016). Pengaruh Capital Intensity Ratio, Inventory Intensity Ratio, Ownership Strucutre dan Profitability Terhadap Effective Tax Rate (ETR)(Studi pada Perusahaan Manufaktur yang Terdaftar di Bursa Efek Indonesia Tahun 2011-2014). Jurnal Ilmiah Mahasiswa Ekonomi Akuntansi, 1(1), 101-119. 
Rahayu, O. O. (2016). Pengaruh Kompensasi Eksekutif, Keterwakilan CFO Wanita, dan Karakteristik Eksekutif Terhadap Tindakan Pajak Agresif (Pada Perusahaan Manufaktur yang Terdaftar di Bursa Efek Indonesia Periode Tahun 2012-2014) (Bachelor's thesis, Jakarta: Fakultas Ekonomi dan Bisnis UIN Syarif Hidayatullah Jakarta).

Sari, D. K., \& Martani, D. (2010). Ownership Characteristics, Corporate Governance, and Tax Aggressiveness. Sriwijaya International Journal of Dynamic Economics and Business, 1(1), 51. https://doi.org/10.29259/sijdeb.v1i1.51-62

Sari, S. P., \& Harto, P. (2014). Kompensasi Eksekutif dan Kinerja Operasional Perbankan Indonesia. Diponegoro Journal of Accounting, 3(2), 10341040.

Sutrisno, Edy. (2011). Human Resource Management. Prenada Media Group. Jakarta.

Wibowo. (2013). Work Management Edition 3. Rajagrafindo.Jakarta. 